\title{
In vitro study on reversal of ovarian cancer cell resistance to cisplatin by naringin via the nuclear factor- $\kappa B$ signaling pathway
}

\author{
HONG ZHU ${ }^{1}$, JUN GAO $^{2}$, LEI WANG $^{3}$, KE-JIAN QIAN $^{4}$ and LI-PING CAI ${ }^{3}$ \\ ${ }^{1}$ Department of Clinical Medicine, Medical College of Nanchang University; ${ }^{2}$ Department of Gynecology, \\ The Third Affiliated Hospital of Nanchang University; Departments of ${ }^{3}$ Gynecology and ${ }^{4}$ Critical Care Medicine, \\ The First Affiliated Hospital of Nanchang University, Nanchang, Jiangxi 330006, P.R. China
}

Received October 27, 2016; Accepted April 11, 2017

DOI: $10.3892 / \mathrm{etm} .2018 .5695$

\begin{abstract}
The aim of the present study was to investigate the mechanism of action by which naringin reverses the resistance of ovarian cancer cells to cisplatin. Semi-quantitative reverse transcription polymerase chain reaction (RT-PCR) and western blotting assays were used to detect the effects of different concentrations of naringin on the expressions of nuclear factor (NF)- $\kappa \mathrm{B}$ and P-glycoprotein (P-gp) in the SKOV3/CDDP cell line. Small interfering RNA (siRNA) targeting NF- $\kappa B$ was designed and synthesized to silence NF- $\kappa \mathrm{B}$, and recombinant plasmid vectors overexpressing NF- $\kappa \mathrm{B}$ were constructed to transfect cells. RT-qPCR and western blotting assays were subsequently performed to detect the effects of NF- $\mathrm{KB}$ on the expression of P-gp at the mRNA and protein levels. Naringin was added to the NF- $\mathrm{kB}$-overexpressing SKOV3/CDDP cells and cultured for $48 \mathrm{~h}$, followed by the detection of the expression of P-gp. RT-PCR and western blotting results demonstrated that the gene and protein expressions of NF- $\mathrm{\kappa B}$ and P-gp were significantly decreased in a dose-dependent manner by naringin treatment $(\mathrm{P}<0.05)$. In cells overexpressing NF- $\kappa \mathrm{B}$, $\mathrm{P}$-gp expression was significantly elevated $(\mathrm{P}<0.05)$, and the expression of P-gp was significantly decreased when NF- $\mathrm{kB}$ was silenced $(\mathrm{P}<0.05)$. Treatment with naringin was able to significantly ameliorate the NF- $\kappa \mathrm{B}$-induced overexpression of $\mathrm{P}$-gp $(\mathrm{P}<0.05)$. These results indicate that naringin is able to inhibit the expression of NF- $\mathrm{KB}$ and P-gp in SKOV3/CDDP
\end{abstract}

Correspondence to: Dr Ke-Jian Qian, Department of Critical Care Medicine, The First Affiliated Hospital of Nanchang University, 17 Yong Wai Street, East Lake, Nanchang, Jiangxi 330006, P.R. China

E-mail: kjqgood@163.com

Dr Li-Ping Cai, Department of Gynecology, The First Affiliated Hospital of Nanchang University, 17 Yong Wai Street, East Lake, Nanchang, Jiangxi 330006, P.R. China

E-mail: cailplp58@163.com

Key words: ovarian cancer, naringin, SKOV3/CDDP cell line, resistance, cisplatin, nuclear factor- $\kappa \mathrm{B}$ signaling pathway cells. Such an inhibitory effect may increase gradually with concentration, and is associated with blockade of the NF- $\kappa B$ signaling pathway. This pathway may represent one of the mechanisms of action by which Naringin reverses resistance to platinum-based agents in ovarian cancer cells.

\section{Introduction}

Ovarian cancer is one of the three malignant tumors of female reproductive system. Statistics revealed that in 2014 , there were $\sim 21,980$ new cases of ovarian cancer and $\sim 14,270$ patients succumbed to the disease in the United States (1). Due to the lack of specific symptoms in early stage of the disease and the lack of effective screening strategies, the majority of cases progress to an advanced stage at the time of primary diagnosis (1). As treatment is for ovarian cancer is long, painful and decreases patients' quality of life, and the recurrence rate is high, it was reported that $60-80 \%$ patients with advanced ovarian cancer relapse 2-3 years after the initial treatment (2) Therefore, ovarian cancer is regarded as the leading cause of mortality in female patients with a reproductive system malignant tumor (1). The most effective treatment for ovarian cancer is surgical cytoreduction and platinum-based chemotherapy (3). Although these treatments have improved the prognosis of patients to some extent, the 5-year survival rate of ovarian cancer remains at approximately $30-40 \%$ (4).

Resistance to platinum-based agents is one of the biggest factors affecting the therapeutic efficacy of pharmacological agents for ovarian cancer (5); therefore, identifying a highly efficient and low-toxic anti-cancer treatment that is able to attenuate resistance to platinum-based agents in ovarian cancer cells is of great importance. The Chinese medicine naringin, which is a natural flavonoid drug, has been demonstrated to have anti-cancer potential, with properties including inhibiting tumor cell proliferation, promoting tumor cell apoptosis and interfering in tumor cell signal transduction (6). A previous study by our group revealed that $20-40 \mu \mathrm{mol} / 1$ naringin was able to significantly inhibit the proliferation of ovarian cancer cells resistant to platinum-based agents in vitro (7); however, the underlying mechanisms by which naringin reverses this resistance remain unclear. A previous study indicated that the nuclear factor (NF)- $\mathrm{kB}$ signaling pathway serves a role in the 
development and progression of ovarian cancer (8). The aim of the present study is to investigate the mechanism of action by which naringin inhibits the expression of P-glycoprotein (P-gp) in a cisplatin-resistant human epithelial ovarian cancer cell line (SKOV3/CDDP) from the perspective of NF- $\mathrm{NB}$ signal transduction, thereby providing an experimental rationale for the development and application of naringin as a treatment for ovarian cancer.

\section{Materials and methods}

Cells and reagents. The cisplatin-resistant ovarian cancer cell line SKOV3/CDDP was purchased from the Chinese Academy of Sciences (Beijing, China). Naringin was provided by the Institute of Pharmacology at Nanchang University (Nanchang, China), and cisplatin was purchased from Qilu Pharmaceutical Co., Ltd. (Shandong, China). RPMI-1640 culture medium and fetal bovine serum (FBS) were purchased from Beijing Soledad Lite-On Technology Co., Ltd. (Beijing, China). Antibodies directed against NF- $\kappa \mathrm{B}$ (cat. no. ab16502) and P-gp (cat. no. ab103477) were purchased from Abcam (Cambridge, UK), horseradish peroxidase-labeled (HRP) goat anti-rabbit IgG (cat. no. TA130015) was purchased from OriGene Technologies, Inc. (Beijing, China). TRIzol was purchased from Invitrogen (Thermo Fisher Scientific, Inc., Waltham, MA, USA). Primers for polymerase chain reaction (PCR) were synthesized by GenScript (Piscataway, NJ, USA). The NF- $\kappa$ B small interfering (si)RNA (sense, 5'-GGAGUA CCCUGAGGCUAUATT-3' and anti-sense, 5'-UAUAGCCUC AGGGUACUCCTT-3'), the negative control siRNA (sense, 5'-UUCUCCGAACGUGUCACGUdTdT-3' and anti-sense, 5'-ACGUGACACGUUCGGAGAAdTdT-3') and plasmid construction was performed by Guangzhou Ruibo Biological Technology Co., Ltd. (Guangzhou, China).

\section{Experimental methods}

Cell culture. SKOV3/CDDP cells were cultured in RPMI-1640 complete culture medium containing $10 \% \mathrm{FBS}, 100 \mathrm{U} / \mathrm{ml}$ penicillin and $100 \mathrm{U} / \mathrm{ml}$ streptomycin at $37^{\circ} \mathrm{C}$ in an atmosphere containing $5 \% \mathrm{CO}_{2}$, with the medium replaced every other day and passage performed every 2-3 days. Cells were cultured to the logarithmic phase and were then randomly assigned to either the normal control group (SKOV3/CDDP cells cultured in RPMI-1640 with $10 \% \mathrm{FBS}, 100 \mathrm{U} / \mathrm{ml}$ penicillin and $100 \mathrm{U} / \mathrm{ml}$ streptomycin at $37^{\circ} \mathrm{C}$ and $5 \% \mathrm{CO}_{2}$ ) or the naringin treatment group (treated with 10,20 or $40 \mu \mathrm{mol} / 1$ naringin). Cells were cultured for $48 \mathrm{~h}$ at $37^{\circ} \mathrm{C}$ with or without naringin according to their group, with 5 duplicates performed for each group. All experiments were performed in triplicate.

Preparation of naringin. Naringin stock solution $(7 \mathrm{mmol} / \mathrm{l})$ was prepared by dissolving $4 \mathrm{mg}$ naringin in $1 \mathrm{ml}$ dimethylsulfoxide. Naringin solution $(200 \mu \mathrm{mol} / \mathrm{l})$ was prepared by adding, $200 \mu 1$ naringin solution to the RPMI-1640 culture medium $(6.8 \mathrm{ml})$. Different concentrations of naringin solution (40, 20 and $10 \mu \mathrm{mol} / \mathrm{l})$ were prepared by diluting this solution with RPMI-1640 to different ratios.

Semi-quantitative reverse transcription (RT) PCR analysis. Total RNA was extracted from cells in the above groups using
TRIzol according to the manufacturer's protocol, and RNA was converted into cDNA using a reverse transcription kit (cat. no. DRR037A; Takara Biotechnology Co., Ltd., Dalian, China) according to the manufacturer's protocol. RT was performed using a thermocycler at $37^{\circ} \mathrm{C}$ for $15 \mathrm{~min}$ and at $85^{\circ} \mathrm{C}$ for $5 \mathrm{sec}$. Primer sequences for PCR are presented in Table I. Amplification was performed using $2 \times$ EasyTa $^{\circledR}$ PCR SuperMix (Beijing Transgen Biotech Co., Ltd., Beijing, China) and a thermocycler as follows: Pre-denaturation at $4^{\circ} \mathrm{C}$ for $5 \mathrm{~min}$, then 29 cycles of denaturation at $94^{\circ} \mathrm{C}$ for $30 \mathrm{sec}$ and annealing at $55^{\circ} \mathrm{C}$ for $30 \mathrm{sec}$, followed by extension at $72^{\circ} \mathrm{C}$ for $30 \mathrm{sec}$ and $72^{\circ} \mathrm{C}$ for $10 \mathrm{~min}$. The PCR products separated on a $2 \%$ agarose gel with ethidium bromide and detected using a chemiluminescent gel imaging system $\left(\right.$ ChemiDoc $^{\mathrm{TM}} \mathrm{XRS}+$; Bio-Rad, Hercules, CA, USA), and the Gel-Pro software (version 4.0; Media Cybernetics, Inc., Rockville, MD, USA) was used to analyze the integrated optical density (IOD) values of the target gene bands.

Western blotting assay. Cells were collected and lysed with protein lysate on ice for $30 \mathrm{~min}$ at $4^{\circ} \mathrm{C}$, followed by centrifugation $12,000 \mathrm{x} \mathrm{g}$ at $4^{\circ} \mathrm{C}$ for $15 \mathrm{~min}$. The supernatant was collected and protein concentrations were determined using the bicinchoninic acid assay method, and each sample was diluted to a final concentration of $2 \mu \mathrm{g} / \mu \mathrm{l}$. A total of $8 \mu \mathrm{g}$ protein samples were loaded per lane and separated by a $4 \%$ (stacking) and 10\% (resolving) SDS-PAGE. The proteins were transferred to a nitrocellulose membrane, which was blocked with $5 \%$ skimmed milk for $2 \mathrm{~h}$ at room temperature. The membrane was then incubated with NF- $\kappa \mathrm{B}, \mathrm{P}-\mathrm{gp}$ and anti-tubulin (cat. no. T3526; Sigma-Aldrich; Merck KGaA, Darmstadt, Germany) primary antibodies overnight at $4^{\circ} \mathrm{C}$, and incubated with the HRP-conjugated secondary antibodies for $2 \mathrm{~h}$ at room temperature. The nitrocellulose membrane was removed for visualization using Pierce ${ }^{\mathrm{TM}}$ ECL Western Blotting Substrate (Thermo Fisher Scientific, Inc.); anti-tubulin was used as the internal control. IOD values of the bands were analyzed using Image Pro Plus software (version 6.0; Media Cybernetics, Inc.) and the relatively quantitative method [IOD (target protein)/IOD (reference protein) ratio] was used to detect the expression level of the target protein.

Cell transfection and intervention. When the SKOV3/CDDP cells reached $90-95 \%$ confluence, they were harvested and seeded in 6-well plates at a density of $2 \times 10^{5}$ cells per well. Cells were cultured in an incubator at $37^{\circ} \mathrm{C}$ in an atmosphere containing $5 \% \mathrm{CO}_{2}$, until cells covered $70-80 \%$ of the plates ( 24 h). Cells were subsequently transfected with 100 pmol plasmids or 100 pmol siRNA according to their group, using Lipofectamine 2000 (Invitrogen; Thermo Fisher Scientific, Inc.) according the manufacturer's protocol. The cells were divided into the following groups: Blank control group (no plasmids or siRNA), empty plasmid control group (plasmids without a gene), NF- $\kappa \mathrm{B}$ overexpression group (NF- $\kappa \mathrm{B}$ plasmids), siRNA control group (negative control siRNA) and the $N F-\kappa B$ siRNA group ( $N F-\kappa B$ siRNA). The expression of P-gp mRNA was detected by semi-quantitative RT-PCR as previously mentioned at $48 \mathrm{~h}$ following transfection of $\mathrm{NF}-\kappa \mathrm{B}$ siRNA or plasmid overexpression, and intervention with naringin was performed in SKOV3/CDDP cells 
Table I. Primer sequences and product size.

\begin{tabular}{llr}
\hline Gene name & \multicolumn{1}{c}{ Primer sequence $\left(5^{\prime}-3^{\prime}\right)$} & Product size (bp) \\
\hline Nuclear factor- $\kappa$ B & F: CAAGGAAGTCCCAGACCAAACC & 121 \\
& R: CTTCCTGCCCTACAGAGGTC & 187 \\
P-glycoprotein & F: TCAGTCAAGTTCAGAGTCTTCA & \\
$\beta$-actin & R: CAAGGCAGTCAG TTACAGTCC & 480 \\
& F: CGGGAAATCGTG CGTGAC \\
\hline
\end{tabular}

F, forward; $R$, reverse.

Table II. Effects of different concentrations of naringin on the expression of nuclear factor- $\kappa \mathrm{B}$ and $\mathrm{P}$-glycoprotein $\mathrm{mRNA}$ in the SKOV3/CDDP cell line.

\begin{tabular}{lcr}
\hline Group & Nuclear factor- $\kappa \mathrm{B}$ & P-glycoprotein \\
\hline Control & $1.227 \pm 0.065$ & $1.253 \pm 0.103$ \\
Naringin $(10 \mu \mathrm{mol} / \mathrm{l})$ & $0.803 \pm 0.067^{\mathrm{a}}$ & $0.907 \pm 0.031^{\mathrm{a}}$ \\
Naringin $(20 \mu \mathrm{mol} / \mathrm{l})$ & $0.640 \pm 0.060^{\mathrm{a}, \mathrm{b}}$ & $0.720 \pm 0.053^{\mathrm{a}, \mathrm{b}}$ \\
Naringin $(40 \mu \mathrm{mol} / \mathrm{l})$ & $0.607 \pm 0.102^{\mathrm{a}, \mathrm{b}}$ & $0.660 \pm 0.060^{\mathrm{a}, \mathrm{b}}$ \\
\hline
\end{tabular}

Data are presented as the mean \pm standard deviation. ${ }^{a} \mathrm{P}<0.001 \mathrm{vs}$. control group; ${ }^{\text {b }}<0.05$ vs. naringin $(10 \mu$ mol/l) group.

Table III. Relative amount of nuclear factor- $\kappa \mathrm{B}$ and P-glycoprotein proteins in the SKOV3/CDDP cell line with different concentrations of naringin.

\begin{tabular}{|c|c|c|}
\hline Group & Nuclear factor- $\kappa \mathrm{B}$ & P-glycoprotein \\
\hline Control group & $4.267 \pm 0.172$ & $3.323 \pm 0.097$ \\
\hline Naringin $(10 \mu \mathrm{mol} / \mathrm{l})$ & $3.297 \pm 0.207^{\mathrm{a}}$ & $2.200 \pm 0.125^{\mathrm{a}}$ \\
\hline Naringin $(20 \mu \mathrm{mol} / \mathrm{l})$ & $2.890 \pm 0.120^{\mathrm{a}, \mathrm{b}}$ & $1.847 \pm 0.093^{\mathrm{a}, \mathrm{b}}$ \\
\hline Naringin $(40 \mu \mathrm{mol} / \mathrm{l})$ & $2.733 \pm 0.097^{\mathrm{a}, \mathrm{b}}$ & $1.703 \pm 0.147^{\mathrm{a}, \mathrm{b}}$ \\
\hline
\end{tabular}

Data are presented as the mean \pm standard deviation. ${ }^{\mathrm{a}} \mathrm{P}<0.001$ vs. control group; ${ }^{\mathrm{b}} \mathrm{P}<0.05$ vs. naringin $(10 \mu \mathrm{mol} / \mathrm{l})$ group.

transfected with $\mathrm{NF}-\kappa \mathrm{B}$ overexpression plasmids. A previous study by our group demonstrated that, the growth rate of drug resistant cells was significantly decreased with a naringin dosage of $20 \mu \mathrm{mol} / 1$ (7). Therefore, a working concentration of $20 \mu \mathrm{mol} / 1$ naringin was used in the present study, and the groups used were as follows: Naringin $(20 \mu \mathrm{mol} / \mathrm{l})+\mathrm{NF}-\kappa \mathrm{B}$ overexpression group and the empty plasmid control group. A total of $48 \mathrm{~h}$ after cell culturing, the expression of $\mathrm{P}-\mathrm{gp}$ mRNA was detected by semi-quantitative RT-PCR as previously mentioned.

Statistical analysis. Statistical analysis was performed using SPSS (version 17.0; SPSS, Inc., Chicago, IL, USA). Student's t-test was used for comparisons of the mean values between the two groups. Intergroup comparisons were made using one-way analysis of variance, and the Fisher's least significant differences t-test was further adopted for pairwise comparison. $\mathrm{P}<0.05$ was considered to indicate a statistically significant difference.

\section{Results}

Effects of naringin on the expression of $N F-\kappa B$ and $P$-gp at both $M R N A$ and protein levels in SKOV3/CDDP cell lines. Semi-quantitative RT-PCR and western blotting results revealed that naringin significantly decreased the expression of $\mathrm{NF}-\kappa \mathrm{B}$ and $\mathrm{P}-\mathrm{gp}$ in a dose-dependent manner $(\mathrm{P}<0.05$; Tables II and III; Fig. 1). Significant differences in NF- $\kappa \mathrm{B}$ and P-gp levels were observed between the $40 \mu \mathrm{mol} / 1$ naringin and $10 \mu \mathrm{mol} / 1$ naringin groups, and between the $20 \mu \mathrm{mol} / 1$ naringin and $10 \mu \mathrm{mol} / \mathrm{l}$ naringin groups (both $\mathrm{P}<0.05$; Tables II and III; Fig. 1). However, there was no significant 
difference between the $40 \mu \mathrm{mol} / 1$ naringin and $20 \mu \mathrm{mol} / \mathrm{l}$ naringin groups.

Effects of overexpression and silencing of $N F-\kappa B$ on P-gp $m R N A$ levels. RT-qPCR revealed that the expression of P-gp mRNA in the NF- $\kappa \mathrm{B}$ overexpression group was significantly upregulated compared with the blank control and empty plasmid control groups (both $\mathrm{P}<0.05$; Table IV; Fig. 2). However, P-gp expression was significantly downregulated in the siRNA NF- $\kappa \mathrm{B}$ group compared with the blank control and siRNA control groups $(\mathrm{P}<0.05$; Table IV; Fig. 2).

Effects of overexpression and silencing of $N F-\kappa B$ and subsequent intervention with naringin. RT-qPCR results demonstrated that P-gp mRNA levels were significantly decreased in the $\mathrm{NF}-\kappa \mathrm{B}$ overexpression group compared with the control group following intervention with naringin $(\mathrm{P}<0.05$; Table V; Fig. 3).

\section{Discussion}

Ovarian cancer is the primary cause of reproductive cancer-related mortality in women in the United States (1). Typically, symptoms do not present in the early stages of ovarian cancer, which renders it difficult to diagnose, and the majority of cases are at an advanced stage when diagnosed (9). At present, the suggested treatment methods of ovarian cancer are surgery and chemotherapy (10-13), and platinum-based agents and paclitaxel have become the first-line chemotherapeutic agents for the treatment of ovarian cancer $(14,15)$. However, the emergence of multi-drug resistant ovarian cancer cells, on which chemotherapeutic agents are ineffective, may reduce the efficacy of chemotherapy (16). Various traditional Chinese medicines have demonstrated potential as anti-cancer agents, with advantages including no toxic reactions and the ability to reverse resistance to chemotherapeutic agents $(17,18)$.

Naringin is a natural flavonoid compound that primarily exists in the peels of pomelo, grapefruit, lime and similar fruits (19). A previous study reported that Naringin exhibits anti-inflammatory, anti-oxidative stress, hypoglycemic, myocardial protective and anti-tumor effects (20). Naringin achieves its anti-tumor effects primarily via the inhibition of tumor cell proliferation, promoting tumor cell apoptosis and interfering in tumor cell signal transduction (21). The results of our previous study suggested that naringin is able to significantly inhibit the proliferation of SKOV3 and SKOV3/CDDP cells in vitro in a time- and dose-dependent manner (22). However, the mechanism by which naringin reverses resistance to platinum-based agents remains unclear. The results of the present study suggest that naringin is able to inhibit the expression of NF- $\mathrm{BB}$ and P-gp proteins in the drug resistant ovarian cancer SKOV3/CDDP cell line in vitro in a concentration-dependent manner.

One important factor leading to chemotherapy resistance is drug efflux from cells. P-gp is an energy-dependent drug pump encoded by the multidrug resistance 1 (MDR1) gene, and its activation and expression are associated with a variety of signaling pathways, such as the phosphoinositide 3-kinase/protein kinase B, mitogen-activated protein kinase (MAPK), NF- $\mathrm{B}$,
Table IV. Relative expression levels of P-glycoprotein mRNA following overexpression and silencing of NF- $\kappa$ B.

\begin{tabular}{ll}
\hline Group & P-glycoprotein \\
\hline Blank control & $0.990 \pm 0.026$ \\
Empty plasmid control & $1.056 \pm 0.085$ \\
siRNA control & $1.030 \pm 0.020$ \\
NF- $\kappa$ B overexpression & $1.810 \pm 0.070^{\mathrm{a}, \mathrm{b}}$ \\
NF- $\kappa \mathrm{B}$ siRNA & $0.437 \pm 0.095^{\mathrm{a}, \mathrm{c}}$ \\
\hline
\end{tabular}

Data are presented as the mean \pm standard deviation. ${ }^{\mathrm{a}} \mathrm{P}<0.001$ vs. blank control group, ${ }^{b} \mathrm{P}<0.001$ vs. empty plasmid control group, ${ }^{\mathrm{c}} \mathrm{P}<0.001$ vs. siRNA control group. NF- $\kappa \mathrm{B}$, nuclear factor- $\kappa \mathrm{B}$; siRNA, small interfering RNA.

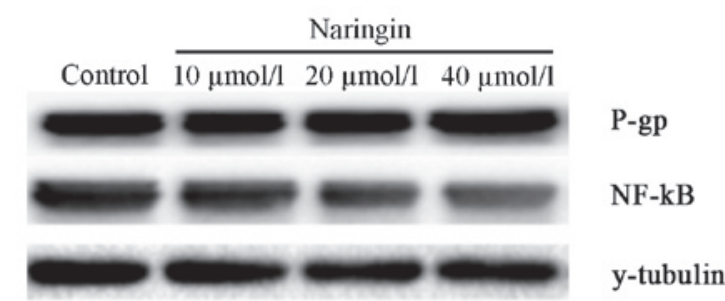

Figure 1. Effects of different concentrations of naringin on the expressions of NF- $\kappa \mathrm{B}$ and P-gp proteins in SKOV3/CDDP cell lines. NF- $\kappa \mathrm{B}$, nuclear factor- $\kappa \mathrm{B} ; \mathrm{P}$-gp, P-glycoprotein.

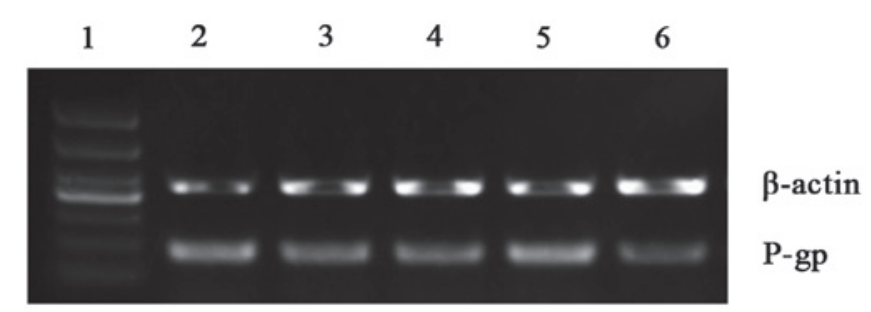

Figure 2. P-gp mRNA expression following the overexpression or silencing of NF-кB. The lanes are as follows: 1, hyperladder; 2, blank control group; 3, empty plasmid control group; 4, siRNA control group; 5, NF- $\kappa$ B overexpression group; $6, \mathrm{NF}-\kappa \mathrm{B}$ siRNA group. P-gp, P-glycoprotein; $\mathrm{NF}-\kappa \mathrm{B}$, nuclear factor- $\kappa \mathrm{B}$; siRNA, small interfering RNA.

Wnt/ $\beta$-catenin Ras-Raf-MAPK kinase-extracellular signal-regulated kinase and prostaglandin E2-cAMP-protein kinase $\mathrm{C}-\mathrm{NF}-\kappa \mathrm{B}$ pathways (23). P-gp discharges multiple cytoxic drugs using ATP within the cells, which increases the resistance of tumor cells to pharmacological agents, thereby causing the resistance of tumor cells (24). MDR1/P-gp is expressed in almost all human tumor cells to different degrees, and its expression in tumors insensitive to chemotherapy or with poor efficacy is often high (25). Previous studies have reported that the sensitivity of some cancer patients to chemotherapy was increased following the administration of P-gp inhibitors (24,26-28). In the present study, downregulation of $\mathrm{P}$-gp protein by naringin was also observed, and therefore it was inferred that the ameliorating effect of naringin on cisplatin resistance of ovarian cancer cells was associated with the downregulation of P-gp. 
Table V. Effects of NF- $\mathrm{B}$ over-expression and intervention with naringin on the expression of mRNA of P-gp.

\begin{tabular}{|c|c|c|c|c|}
\hline Group & P-gp & $\mathrm{NF}-\kappa \mathrm{B}$ & T-value & P-value \\
\hline Naringin $(20 \mu \mathrm{mol} / \mathrm{l})+\mathrm{NF}-\kappa \mathrm{B}$ overexpression group & $1.077 \pm 0.065^{\mathrm{a}}$ & $0.610 \pm 0.089^{\mathrm{a}}$ & -8.496 & 0.001 \\
\hline Empty plasmid control group & $1.753 \pm 0.080$ & $1.797 \pm 0.064$ & -12.266 & 0.000 \\
\hline
\end{tabular}

Data are presented as the mean \pm standard deviation. ${ }^{a} \mathrm{P}<0.01$ vs. control group. $\mathrm{NF}-\kappa \mathrm{B}$, nuclear factor- $\kappa \mathrm{B} ; \mathrm{P}$-gp, $\mathrm{P}$-glycoprotein.
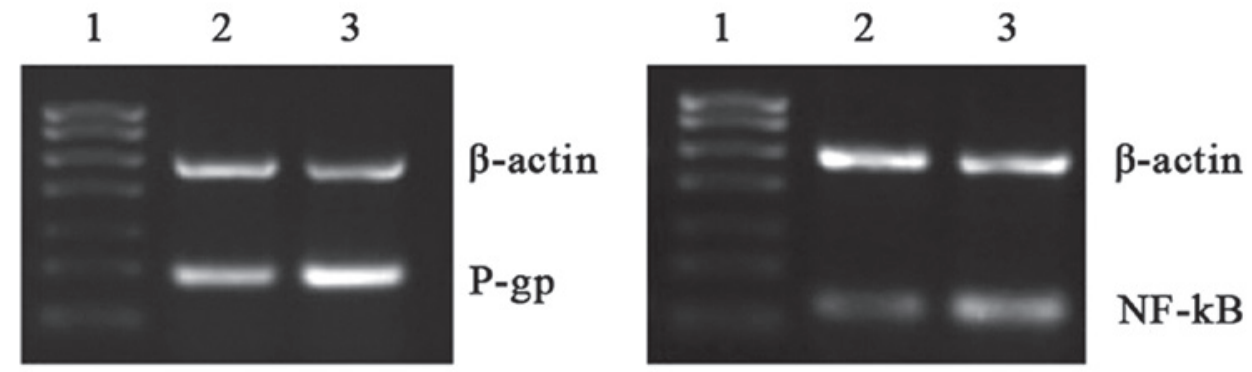

Figure 3. Effects of NF- $\mathrm{kB}$ overexpression + intervention with naringin on the expression of P-gp mRNA. The lanes are as follows: 1, hyperladder; 2, NF- $\mathrm{kB}$

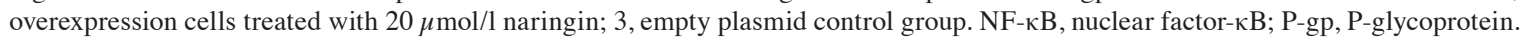

The results of the present study indicate that naringin inhibits the expression of $\mathrm{NF}-\kappa \mathrm{B}$ in SKOV3/CDDP cells. Studies have reported that $\mathrm{NF}-\kappa \mathrm{B}$ is associated with the development, progression and metastasis of tumors, and many proteins it encodes promote tumor growth (29-31). One study demonstrated that $\mathrm{NF}-\kappa \mathrm{B}$ was persistently highly expressed in cisplatin-resistant ovarian cancer cells, and that it served an important role in drug resistance of ovarian cancer cells (5). $\mathrm{NF}-\kappa \mathrm{B}$ exerts anti-apoptotic effects via regulating downstream target proteins B-cell lymphoma (Bcl)-xL, Bcl-2, Fas/FasL, $\mathrm{X}$-linked inhibitor of apoptosis protein, survivin, cellular inhibitor of apoptosis protein $1 / 2$, cyclin-dependent kinase2, vascular endothelial growth factor and cyclooxygenase-2, whereby the viability of tumor cells is increased, resulting in chemotherapy resistance (8).

The NF- $\mathrm{KB}$ signaling pathway has been demonstrated by a number of studies to be associated with the development and progression of tumors $(32,33)$. To further investigate the association between $\mathrm{NF}-\kappa \mathrm{B}$ and $\mathrm{P}-\mathrm{gp}$, which is an important gene contributing to drug resistance in ovarian cancer, the expression of P-gp mRNA was assessed before and after overexpression or silencing of $\mathrm{NF}-\kappa \mathrm{B}$. The present results indicated that the expression of P-gp mRNA in the $\mathrm{NF}-\kappa \mathrm{B}$ overexpression group was increased, whereas it was decreased in the siRNA $N F-\kappa B$ group. This indicates that $\mathrm{P}-\mathrm{gp}$ is subject to regulation by the $\mathrm{NF}-\kappa \mathrm{B}$ signaling pathway. In a later experiment, naringin was added as an intervention condition, and the expression of P-gp mRNA in the NF- $\kappa \mathrm{B}$ overexpression group was decreased. These results suggest that the naringin-induced reversal of ovarian cancer resistance to platinum-based agents may be associated with the regulation of $\mathrm{P}-\mathrm{gp}$ via the $\mathrm{NF}-\kappa \mathrm{B}$ signaling pathway in the SKOV3/CDDP cell line.

In conclusion, naringin is able to inhibit the expression of $\mathrm{NF}-\kappa \mathrm{B}$ and $\mathrm{P}-\mathrm{gp}$ in SKOV3/CDDP cells. Such an inhibitory effect may be dose-dependent, and is associated with the blockade of the NF- $\mathrm{NB}$ signaling pathway.

\section{Acknowledgements}

The present study was supported by the Science And Technology Plan Projects of Jiangxi Province (grant no. 20152ACG70022).

\section{References}

1. Siegel RL, Miller KD and Jemal A: Cancer statistics, 2015. CA Cancer J Clin 65: 5-29, 2015.

2. Eoh KJ, Lee JY, Yoon JW, Nam EJ, Kim S, Kim SW and Kim YT: Role of systematic lymphadenectomy as part of primary debulking surgery for optimally cytoreduced advanced ovarian cancer: Reappraisal in the era of radical surgery. Oncotarget 8: 37807-37816, 2017.

3. Jessmon P,Boulanger T,Zhou W and Patwardhan P: Epidemiology and treatment patterns of epithelial ovarian cancer. Expert Rev Anticancer Ther 17: 427-437, 2017.

4. Poveda Velasco A, Casado Herráez A, Cervantes Ruipérez A, Gallardo Rincón D, García García E, González Martín A, López García G, Mendiola Fernández C and Ojeda González B; GEICO Group: Treatment guidelines in ovarian cancer. Clin Transl Oncol 9: 308-316, 2007.

5. Choi M, Fuller CD, Thomas CR Jr and Wang SJ: Conditional survival in ovarian cancer: Results from the SEER dataset 1988-2001. Gynecol Oncol 109: 203-209, 2008.

6. Birt DF, Hendrieh S and Wang W: Dietary agents in cancer prevention: Flavonoids and isoflavonoids. Pharmacol Thera 90: 157-177, 2001.

7. Song SH, Hu X, Xiong YQ and Cai LP: Effects of Naringin on expression of COX-2 mRNA and protein in human ovarian cancer cell line SKOV3. Chin J Clin Pharmacol Ther 18: 271-276, 2013 (In Chinese).

8. Godwin P, Baird AM, Heavey S, Barr MP, O'Byrne KJ and Gately K: Targeting nuclear factor kappaB to overcome resistance to chemotherapy. Front Oncol 3: 120, 2013.

9. Goff B: Symptoms associated with ovarian cancer. Clin Obstet Gynecol 55: 36-42, 2012.

10. Mucciolk M and Benencia F: Toll-like receptors in ovarian cancer as targets for immunotherapies. Front Immunol 5: 341, 2014. 
11. Bookman MA: First line chemotherapy in epithelial ovarian cancer. Clin Obstet Gynecol 55: 96-113, 2012.

12. Raja FA, Counsell N, Colombo N, Pfisterer J, du Bois A, Parmar MK, Vergote IB, Gonzalez-Martin A, Alberts DS, Plante $\mathrm{M}$, et al: Platinum versus platinum, Combination chemotherapy in platinum-sensitive recurrent ovarian cancer: A meta-analysis using individual patient data. Ann Oncol 24: 3028-3034, 2013.

13. Schwab CL, English DP, Roque DM and Santin AD: Taxanes: Their impact on gynecologic malignancy. Anticancer Drugs 25: 522-535, 2014.

14. Pellicciotta I, Yang CP, Venditti CA, Goldberg GL and Shahabi S: Response to microtubule-interacting agents in primary epithelial ovarian cancer cells. Cancer Cell Int 13: 33, 2013.

15. Sorbe B, Graflund M, Nygren L and Horvath G: A study of docetaxel weekly or every three weeks in combination with carboplatin as first line chemotherapy in epithelial ovarian cancer: Hematological and non-hematological toxicity proftes. Oncol Lett 5: 1140-1148, 2014.

16. Colombo PE, Fabbro M, Theillet C, Bibeau F, Rouanet P and Ray-Coquard I: Sensitivity and resistance to treatment in the primary management of epithelial ovarian cancer. Crit Rev Oncol Hematol 89: 207-216, 2013.

17. Wang Y, Han A, Chen E, Singh RK, Chichester CO, Moore RG, Singh AP and Vorsa N: The cranberry flavonoids PAC DP-9 and quercetin aglycone induce cytotoxicity and cell cycle arrest and increase cisplatin sensitivity in ovarian cancer cells. Int $\mathbf{J}$ Oncol 46: 1924-1934, 2015.

18. Li J, Wang Y, Lei JC, Hao Y, Yang Y, Yang CX and Yu JQ: Sensitisation of ovarian cancer cells to cisplatin by flavonoids from Scutellaria barbata. Nat Prod Res 28: 683-689, 2014.

19. Salmah Y, Hasanah MG and Gan SK: Naringin content in local citrus fruits. Food Chem 37: 113-121, 1990.

20. You Q and Wu K: Naringin cardiovascular pharmacological effects. Guangdong Med J 31: 3006-3008, 2010.

21. Meiyanto E, Hermawan A and Anindyajati: Natural products for cancer-targeted therapy: Citrus flavonoids as potent chemopreventive agents. Asian Pac J Cancer Prev 13: 427-436, 2012.

22. Wang L and Cai LP: Reversal of drug resistance and reversal mechanism of human ovarian cancer resistant SKOV3/DDP cells by naringin. J Clin Oncol 21: 598-602, 2016.

23. Dharmapuri G, Doneti R, Philip GH and Kalle AM: Celecoxib sensitize simatinib-resistant K562 cell stoimatinib by inhibiting MRP1-5, ABCA2 and ABCG2 transporters via Wnt and Ras signaling pathways. Leuk Res 39: 696-701, 2015.
24. Januchowski R, Wojtowicz K, Sujka-Kordowska P, Andrzejewska M and Zabel M: MDR gene expression analysis of six drug-resistant ovarian cancer cell lines. Biomed Res Int 2013: 241763, 2013

25. Januchowski R, Sterzyńska K, Zaorska K, Sosińska $P$, Klejewski A, Brazert $M$, Nowicki $M$ and Zabel $M$ : Analysis of MDR genes expression and cross-resistance in eight drug resistant ovarian cancer cell lines. J Ovarian Res 9: $65,2016$.

26. Abraham J, Salama NN and Azab AK: The role of P-glycoprotein in drug resistance in multiple myeloma. Leuk Lymphoma 156: 26-33, 2015.

27. Tomiyasu H, Watanabe M, Sugita K, Goto-Koshino Y, Fujino Y, Ohno K, Sugano S and Tsujimoto H: Regulations of ABCB1 and ABCG2 expression through MAPK pathways in acute lymphoblastic leukemia cell lines. Anticancer Res 33: 5317-5323, 2013.

28. Vasconcelos FC, Silva KL, Souza PS, Silva LF, Moellmann-Coelho A, Klumb CE and Maia RC: Variation of MDR proteins expression and activity levels according to clinical status and evolution of CML patients. Cytometry B Clin Cytom 80: 158-166, 2011.

29. Allen CT, Ricker JL, Chen Z and Van Waes C: Role of activated nuclear factor-kappaB in the pathogenesis and therapy of squamous cell carcinoma of the head and neck. Head Neck 29: 959-971, 2007.

30. Weichert W, Boehm M, Gekeler V, Bahra M, Langrehr J, Neuhaus P, Denkert C, Imre G, Weller C, Hofmann HP, et al: High expression of Rel A/P65is associated with activation of nuclear factor-kappa B-dependent signaling in pancreatic cancer and marks a patient population with poor prognosis. $\mathrm{Br} \mathrm{J}$ Cancer 97: 523-530, 2007.

31. Bivona TG, Hieronymus H, Parker J, Chang K, Taron M, Rosell R, Moonsamy P, Dahlman K, Miller VA, Costa C, et al: FAS and NF- $\kappa B$ signaling modulate dependence of lung cancers on mutant EGFR. Nature 471: 523-526, 2011.

32. Napetschnig $J$ and $\mathrm{Wu} \mathrm{H}$ : Molecular basis of NF- $\kappa \mathrm{B}$ signaling. Annu Rev Biophys 42: 443-468, 2013.

33. Cho HH, Song JS, Yu JM, Yu SS, Choi SJ, Kim DH and Jung JS: Differential effect of NF-kappaB activity on beta-catenin/Tcf pathway in various cancer cells. FEBS Lett 582: 616-622, 2008. 